\title{
Dekonstruksi Histori Hadis
}

\author{
Khairil Ikhsan Siregar \\ Universitas Negeri Jakarta \\ khairil_siregar@unj.ac.id
}

\begin{abstract}
This paper calls for a deconstruction of the hadith, since historical rationalization and historical accounting methods tend to rely only on the method of sanad criticism, propelled by scholars of hadith in the second and third centuries of the Hijri century. This also needs to be done because there are mistakes interpretation of the sunnah and the desire pemembangaan understanding of Muslims so as to close the progress of Muslims in berkehidupan. In the history of Muslims, the reliability of ulumul hadith has never been a meaningful challenge from Islamic scholars. There are some scholars who doubt its reliability but have no meaningful sympathy from Muslims, therefore it is necessary to adopt Western thinkers' efforts in researching Islamic scholarship as motivation in obtaining the accuracy of Islamic teachings, by seeking alternative new methods such as the necessity of deconstruction and reconstruction against hadith.
\end{abstract}

\section{Keywords: Hadith, Deconstruction, Reconstruction}

\begin{abstract}
Abstrak
Tulisan ini menghendaki adanya dekonstruksi terhadap hadis, karena rasionalisasi sejarah dan metode pembukuan sejarah cenderung hanya mengandalkan metode kritik sanad saja, yang digerakkan ulama hadis pada abad paruh kedua dan paruh abad ketiga Hijriah. Hal ini juga perlu dilakukan karena ada kesalahan-kesalahan interpretasi terhadap sunnah dan keinginan pelembangaan pemahaman umat Islam sehingga menutup kemajuan umat Islam dalam berkehidupan. Dalam sejarah umat Islam, reliabilitas ulumul hadis tidak pernah mendapat tantangan berarti dari sarjana Islam. Ada beberapa sarjana yang meragukan reliabilitasnya, tapi tidak mendapat simpati berarti dari umat Islam, oleh karena itu perlu untuk mengadopsi upaya pemikir Barat dalam meneliti keilmuan Islam sebagai motivasi dalam mendapat keakurasian referensi ajaran Islam, dengan mencari alternatif metodemetode baru seperti perlunya dekonstruksi dan rekonstruksi terhadap hadis.
\end{abstract}

\section{Kata Kunci : Hadis, Dekontruksi, Rekonstruksi}

\section{A. Pendahuluan}

Dekonstruksi adalah sebuah metode pembacaan teks. Dengan dekonstruksi ditunjukkan bahwa dalam setiap teks selalu hadir anggapan-anggapan yang dianggap absolut. Padahal, setiap anggapan selalu kontekstual, anggapan selalu hadir sebagai konstruksi sosial yang menyejarah. Maksudnya, anggapan-anggapan tersebut tidak 
mengacu kepada makna final. Anggapan-anggapan tersebut hadir sebagai jejak (trace) yang bisa dirunut pembentukannya dalam sejarah.

Apakah sunnah dalam perkembangannya mengalami transisi yang membuatnya terpenjara karena kebijakan atau lembaga? Tentu ada jawaban sejarah sunnah yang telah difahami masyarakat muslim sebagai sumber syar'i yang kedua setelah kitab al-Qur'an selama lebih dari 14 abad. Data-data yang ada dalam literatur Islam menunjukkan bahwa sunnah secara empirik telah mengalami perubahan, sunnah sebagai sejarah sehingga ia dijadikan dokumen-dokumen yang berfungsi dogmatis bagi kaum muslimin. Maka sunnah menjadi dokumen-dokumen doktrin seperti halnya al-Qur'an.

Paradigma umat muslim terhadap sunnah terdiri dari perbuatan, perkataan, dan taqrir Nabi, atau dengan nama lain hadis yang disusun menjadi kitab-kitab karya ulama hadis pada abad kedua dan ketiga yang kemudian dipahami sebagai dokumen-dokumen monumental yang dogmatis. Hal itu, telah ter-refleksikan dalam pandangan sikap masyarakat muslim yang berfikir konservatif atau tradisional.

Bila mengacu pada tanggapan dari para pemerhati dan pemikir keislaman yang kritis, terlihat bahwa sudah cukup lama mereka peduli pada ajaran Islam, terutama hadis an-nabi saw. Begitu juga penelitian terhadapnya, telah banyak juga dilakukan mereka, termasuk di dalamnya adalah para orientalis karena mengingat Hadis Nabi saw adalah juga petunjuk bagi umat Islam setelah al-Qur'an yang sekaligus merupakan penjelas utama alQur'an. ${ }^{1}$

Akan tetapi kenyataan sejarah menunjukkan bahwa sumber hadis hanya merujuk ke abad pertama dan kedua. Selama dekade ini juga telah mengalami kritikan-kritikan hadis langsung dari sahabat kepada Nabi dan meminta klarifikasi dari Nabi. Di masa ini, terjadinya fitnah di tengah-tengah masyarakat muslim yang berakibat saling membunuh antara kaum muslimin dan menjadikan kaum muslimin terpecah belah menjadi kelompokkelompok sehingga untuk menguatkan kelompok masing-masing mereka banyak yang memalsukan al-hadits. Sehingga hadis mengalami peningkatan jumlah yang disandarkan kepada Nabi SAW'2.

Hal tersebut telah mendapat perhatian di kalangan kaum muslimin dan juga di kalangan Barat (orientalis), tentang hadis yang bersumber hanya kepada abad pertama dan kedua. Menyadari hal tersebut, ulama hadits di abad ketiga kemudian mencetuskan suatu

\footnotetext{
${ }^{1}$ Imran Zabidi, Kritik Matan Hadis Menurut Al-Thahâwî Dalam Bukunya syarh Musykil Al-Ătsâr (Disertasi UIN Syarif Hidayatullah Jakarta) Jakarta: Perpustakaan Pascasarjana UIN Jakarta, 2008

${ }^{2}$ Yuslim, Nawir, Ulumul Hadis, Jakarta: Mutiara Sumber Widya, 2001, h.89
} 
disiplin ilmu, yaitu ilmu hadits. Begitu juga Barat dari kelompok skeptis terhadap hadis melontarkan kritik pedas terhadap sumber syari'ah Islam yang kedua ini.

\section{B. Diskursus Tentang Hadis di Barat}

Ketika para sarjana Barat memasuki area keilmuan islam, yaitu penelitian tentang sumber dan asal usul ajaran Islam, mereka dihadapkan pada pertanyaan tentang apakah dan sejauh mana hadis-hadis atau riwayat-riwayat tentang hadis Nabi dan sejauh mana generasi Islam pertama dipercaya secara historis. Pada fase awal kesarjanaan Barat, mereka menunjukkan kepercayaan yang tinggi terhadap literatur hadits dan riwayat-riwayat tentang Nabi dan generasi Islam awal. Tetapi sejak paruh kedua abad kesembilan belas, skeptisme tentang otentisitas sumber periwayatan hadis menjadi perdebatan dalam kesarjanaan Barat yang didominasi kelompok skeptis. Di antaranya, seperti Ignaz Goldziher, Joseph Schacht, Wansbrough, Patricia Crone, Michael Cook, dan Norman Calder berpengaruh secara dramatis terhadap karya-karya sarjana Barat. Akan tetapi, tidak semua sarjana Barat dapat digolongkan dalam aliran atau "mazhab" skeptis. Sarjana seperti Joseph Van Ess, Harald Motzki, Miklos Muranyi, M.J.Kister, Fueck, dan Schoeler bereaksi keras terhadap sejumlah premis, kesimpulan, dan metodologi para kelompok skeptis. Mereka dapat digolongkan sebagai non skeptis. Perdebatan antara kedua kelompok ini sangat tajam selama dua dekade terakhir ${ }^{3}$.

Singkatnya, diskursus hadis di Barat selalu merujuk kepada nama Ignaz Goldziher (Honggaria) dan Joseph Schacht (Austria), dan untuk yang masih hidup G.H.A. Juynboll (Belanda), Harald Motzki (Jerman), dan beberapa nama lain. Di mata Orientalis, kedua nama pertama dianggap seperti Ibn al-Salah (pendekar ulum al-hadith Muslim) atau Ibn Hajar dalam dunia Islam. Sedangkan G. H. A. Juynboll dan Harald Motzki, dianggap (kurang lebih) seperti Muhammad Shakir, al-Albani, dan al-Saqqaf atau al-Gumari dalam dunia Islam. Kedua nama pertama (Goldziher dan Schacht) telah wafat, tapi meninggalkan pengaruh global dan menciptakan mazhab skeptis di Barat. Di masa Goldziher (Mohammedanische Studien,1890) dan Schacht (The Origins, 1950), mayoritas sarjana Barat skeptis terhadap literatur Islam, termasuk hadis. Diskursus masa awal Islam-pun (abad pertama dan kedua) dianggap tidak tersentuh karena minusnya sumber yang tersedia untuk itu. Secara umum, mazdhab skeptis berpendapat bahwa pengetahuan dan informasi tentang masa awal Islam (abad pertama dan kedua hijriah) hanyalah perpsepsi komunitas

\footnotetext{
${ }^{3}$ http://www.grahadis.uim.ac.id/index.php.optio
} 
Muslim abad ketiga. Literatur yang ada tidak lebih dari sekedar refleksi peta konflik yang tidak dapat memantulkan realitas seperti digambarkan oleh sumber itu sendiri ${ }^{4}$.

Beberapa dekade terahir mazhab skeptis yang telah mapan di Barat tidak lagi menjadi satu-satunya trend yang mendominasi diskursus studi Islam di Barat. Mazhab nonskeptis yang dikomandani oleh sejumlah Orientalis sekaliber Motzki, Fuec, Scheoler, Schoeler, dan lain-lain, turut meramaikan diskursus masa awal Islam. Lewat metodologi yang mereka kembangkan, mereka melakukan rekonstruksi sejarah untuk melihat sejauh mana literatur abad ketiga dapat memberikan informasi akurat tentang abad pertama dan kedua hijriah. ${ }^{5}$

Sarjana Muslim, Fuat Sezgin, sarjana berkebangsaan Turki yang menulis karya masterpiece Geschichte des arabishen Schrifftums dan Muhammad Azmi telah terlibat dalam diskursus hadis di barat, namun radiasi pengaruhnya terasa sangat marginal di Barat. Dalam studi yang cukup serius, Sezgin dan Azmi berkesimpulan bahwa proses transmisi hadis nabi secara tertulis dimulai sejak masa sahabat sampai pada masa pengumpulan hadis di pertengahan abad ketiga hijriah. Dengan kata lain, literatur hadis yang diwarisi dari pertengahan abad ketiga adalah hasil dari periwayatan tertulis dari masa sahabat, sehingga kualitas historisitasnya terjamin tanpa keraguan. Kesimpulan Sezgin dan Azmi didukung oleh Nabi Abbott. Kelemahan ketiga sarjana ini menurut pengkritiknya adalah mereka menggunakan sumber atau literatur pada abad ketiga untuk merekonstruksi peristiwa abad pertama. Dan metode yang digunakan adalah metode penyandaran atau isnad. Oleh para Orientalis, argumen-argumen yang diajukannya dianggap circular $^{6}$.

Penulis melihat sarjana Barat mangangkat rasionalalisasi dokumen-dokumen hadis yang menjadi sumber ajaran yang kedua dalam ajaran Islam, menjadi arjaran dogmatis bagi masyarakat muslim. Sedangkan memahami hadis-hadis dengan menyandarkan kepada histori telah lama ditinggalkan. Maka Barat menyodorkan metode kritik hitoris dan logika kritik sangat netral dan mendamaikan kritik sanad (eskternal) dan kritik matan (internal) hadis. Hal ini bisa dicontohkan dengan hadis yang diriwayatkan oleh Abu Huraira; Abu Huraira berkata " Nabi Muhammad SAW bersabda kepada pamannya Abu Thalib, 'katakanlah bahwa tidak ada Tuhan kecuali Allah, dan aku bersaksi untuk di hari akhir, tapi Beliau menolak' ... di tempat lain Abu Huraira berkata, “ Nabi SAW bersabda

\footnotetext{
${ }^{4}$ http://www.grahadis.uim.ac.id/index.php.optio

${ }^{5}$ M.'Ijjaj, al-Khathib, Ushul al-Hadits -wa- 'Ulumuh-wa-Mushthalahu, Lubnan: Dar-Al-Fikr-alHadits, 1967, h.45

6 http://www.grahadis.uim.ac.id/index.php.optio
} 
kepada pamannya menjelang wafat, ' katakanlah bahwa tidak ada tuhan kecuali Allah dan aku bersaksi padamu di hari akhir.' Tapi paman beliau menolak".

Abu Thalib meninggal dunia pada tahun ke-10 kenabian SAW yaitu tiga tahun sebelum Hijriah. Jadi, ia meninggal sepuluh tahu sebelum Abu Huraira datang ke Hijaz. Bagaimana mungkin Abu Huraira bertemu dengan Nabi dan menyaksikan wafatnya paman beliau. Lalu kenapa Abu Huraira meriwayatkan seakan-akan dia hadir dan menyaksikan langsung peristiwa tersebut?. Disinilah fungsi kritik historis bisa dibuktikan ${ }^{7}$.

\section{Problematika Ulumul Hadis}

Metode yang digunakan oleh para sarjana Muslim klasik untuk menyandarkan sebuah hadits kepada Nabi tidak mendapat tantangan yang signifikan dari sarjana Muslim modern. Memang terdapat sejumlah sarjana modern yang mencoba menunjukkan resistensinya terhadap ulumul hadis, tetapi mereka gagal mendapatkan simpati mayoritas sarjana Muslim.

Informasi tentang Nabi yang terekam dalam buku-buku hadis laksana pecahanpecahan kaca yang harus direkonstruksi supaya dapat memantulkan berita-berita akurat tentang Nabi. Meskipun hadis-hadis tersebut telah diseleksi oleh para kolektornya (misalnya al-Bukhari, Muslim, Tirmizi, Ibn Majah, Abu Daud, Nasai). Namun, kenyataan bahwa para kolektor ini hidup pada abad ke tiga Hijriah (dua ratus tahun lebih setelah nabi wafat), pertanyaan epistimologis muncul: sejauh mana tingkat akurasi metodologi para kolektor ini dalam menyeleksi hadis-hadisnya? Apakah metodologi mereka sama dengan metodologi yang populer kita kenal dengan ulum al-hadis?

Al-Bukhari yang dikenal sebagai the man of hadits, misalnya, tidak pernah menjelaskan metodologinya secara detail. Ulumul hadis yang menurut mayoritas sarjana Islam sangat akurat menyimpan sejumlah pertanyaan-pertanyaan epistimilogis yang tidak terjawab secara empiris. Ulumul hadis diterima dan dianggap sesuatu yang taken for granted.

Kecenderungan sebagian di antara kaum muslimin adalah menolak atau menerima sebuah hadis tanpa meneliti historinya. Apabila sebuah hadits disebutkan dalam Sahih alBukahi atau Muslim, apalagi kalau keduanya menyebutkannya, lebih-lebih lagi kalau disebutkan dalam kutub al-sitta, al-tis'a, maka tidak diragukan lagi hadis tersebut menurut

${ }^{7}$ Ali Mutafa Yakub, Kritik Hadis, Jakarta: Pustaka Firdaus, 2008, h.76 
mayoritas sarjana Islam adalah sahih, sehingga analisis historis terhadapnya tak lagi dipentingkan. Benarkah sikap seperti itu? Terdapatnya sebuah hadis dalam sejumlah kitabkitab hadis bukanlah jaminan akan historisitasnya, karena boleh jadi hadis tersebut diriwayatkan secara passive pada generasi tertentu (paruh kedua abad kedua dan seterusnya sampai ke masa mukharrij), tapi pada generasi sebelumnya (paruh pertama abad kedua dan sebelumnya sampai masa Nabi) diriwayatkan secara ahad (single strand). Singkatnya, semua hadits yang terekam dalam kitab hadis harus tunduk pada kritik sejarah. Secara umum literatur hadis memiliki karakter sebagai berikut: Nabi-----Satu Sahabat-----satu Tabiin----satu fulan- satu fulan------sejumlah perawi sampai ke mukharrij (collector) .

Terdapat sejumlah inkonsistensi metode kritik hadits. Ada gap yang cukup menganga antara teori dan fakta, antara teori ulumul hadits dengan keadaan objektif literatur hadis. Kalau teori ulumul hadis di aplikasikan secara ketat, bisa jadi kualitas literatur hadis menurun secara sangat signifikan. Contoh sederhana, teori ulumul hadis mengajarkan kepada kita bahwa riwayat seorang mudallis tidak bisa dijadikan hujja apabila ia tidak berterus terang atau ia tidak menyatakan secara tegas sumber informan-nya, misalnya dengan mengatakan 'an atau sejenisnya, kecuali kalau riwayat tersebut dikuatkan oleh riwayat perawi lain yang tsiqah. Mari kita menguji teori ini secara praktis dalam literatur hadits dengan mengambil contoh kasus Abu Zubair. Abu Zubair, seorang tabi'in yang di klaim oleh mayoritas kritikus hadis sebagai mudallis. ${ }^{8}$

Dengan berpedoman pada teori tersebut di atas maka semua hadits yang diriwayatkannya secara tidak langsung (misalnya dengan menggunakan kata-kata 'an dan sejenisnya) tidak bisa dijadikan hujja (dalil yang kuat), kecuali kalau ada hadis lain yang menguatkannya. Dalam kitab-kitab hadis, kutub al-sitta, misalnya, ditemukan ratusan hadis yang diriwatkan oleh Abu Zubair, dimana dia tidak menjelaskan cara penerimaannya apakah lansung dari informannya atau tidak. Dalam kutub al-sitta, Abu al-Zubair meriwayatkan 360 hadis dari Sahabat Jabir bin Abdullah saja, ${ }^{9}$ belum termasuk hadis yang diriwayatkan Abu al-Zubair dari Sahabat lain. Jumlah tersebut akan bertambah lagi apabila diteliti riwayat Abu al-Zubair dalam kitab kitab hadis yang lain. Dari 360 hadis tersebut, Muslim merekam 194, Abu Dawud 83, Tirmizi 52, Nasai 141 dan Ibn Maja 78 hadis. Sebenarnya, jalur Abu Zubair - Jabir dalam kutub al-sitta sebanyak 548, tapi beberapa di antaranya hadis-hadisnya berulang. Dari 194 hadis riwayat Abu al-Zubair yang terdapat

\footnotetext{
${ }^{8}$ Al-Razi, al-Jarh wa al-tadil, vol. 8. hal. 75; Ibn Hajar, Tahdhib al-tahdhib, vol. 9, hal. 441

${ }^{9}$ Kamaruddin Amin, The Reliability of Hadith Transmission, A Reexamination of Hadith Critical Methods, Bonn 2005)
} 
dalam Sahih Muslim, 125 di antaranya Abu Zubair menggunakan kata-kata 'an dan sejenisnya, hanya 69 hadis dimana ia menggunakan kata kata haddathana dan sejenisnya. Menurut teori ulumul hadis, riwayat seperti ini tidak bisa di jadikan hujja. Kalau demikian halnya maka menurut ulumul hadis, kita harus menolak ratusan hadis yang terdapat dalam kitab hadis termasuk dalam sahih Buhari dan Muslim ${ }^{10}$.

Kasus yang sama juga terjadi pada perawi Hasan al-Basri. Oleh mayoritas kritikus hadis, Hasan al-Basri dianggap sebagai mudallis. ${ }^{11}$ Meskipun ada juga yang memujinya sebagai faqih dan memiliki muruah (keperibadian ) yang baik, tapi ia tetap diklaim telah melakukan tadlis. ${ }^{12}$ Terlepas dari apa yang disampaikan oleh para kritikus hadis tentang tokoh ini, kemunculannya sebagai perawi hadis yang begitu sering dalam kitab hadis menjadikannya sebagai tokoh yang terlalu penting untuk diabaikan. Dalam kutub al-sitta saja Hasan al-Basri meriwayatkan tidak kurang dari 281 hadis. 43 hadis di antaranya terdapat dalam Sahih Bukhari dan Muslim (the most highly appreciated hadith collections). 31 hadis terdapat dalam Sahih al-Bukhari dan 12 terdapat dalam Sahih Muslim. ${ }^{13}$

Dari 31 hadis yang terdapat dalam Sahih al-Bukhari, hanya delapan kali Hasan alBasari mengatakan haddathana dan sejenisnya, yang dianggap oleh para kritikus hadis beliau mendengarnya secara langsung dari informantnya. Dalam 17 hadis, Hasan al-Basri ber- 'an'ana, yang oleh para kritikus hadis dianggap tidak menerimanya secara langsung. Selebihnya, hadis Hasan al-Basri dalam Sahih Bukhari adalah mursal. Dalam Sahih Muslim hanya dua kali Hasan al-Basri mengatakan haddathana dari 12 hadis yang diriwayatkannya. Kesimpulan apa yang dapat ditarik dari data data ini? Dengan menerapkan teori ulumul hadis pada kasus Hasan al-Basri, maka 17 hadis dalam al-Bukhari dan delapan hadis dalam Sahih Muslim harus ditolak, atau paling tidak kehujjahannya harus di "gantung" sampai ada hadis lain yang tsiqah yang dapat menguatkannya.

Ulumul hadis juga mengajarkan bahwa dalam transmisi (periwayatan) hadis seorang perawi harus tsiqa (reliable). Cara menentukan ke-tsiqah-an perawi adalah dengan merujuk kepada buku-buku biografi perawi dan dengan membandingkan riwayatnya dengan riwayat yang lain. Pertanyaannya, sejauh mana keakuratan penilaian penulis buku biografi terhadap seorang perawi, sementara masa hidup mereka sangat berjauhan? Penulusuran terhadap buku biografi mengindikasikan bahwa penilain tersebut sering kurang akurat, sehingga

10 http://www.grahadis.uim.ac.id/index.php?.optio

11 Ibn Hajar al-Asqalani memasukkannya dalam kelompok mudallis. Lihat Ibn Hajar, Tabaqat almudallisisn, Cairo 1322, hal. 8, 14.

12 Al-Mizzi, Tahdhib al-kamal, vol. 6, hal. 109, 125; Ibn Sa'd, Tabaqat, vol. 7, hal. 161, 157-8.

13 Lihat Kamaruddin Amin, The Relibility of Hadith Transmission, Bonn 2005. 
penentuan kualitas perawi yang hanya didasarkan atas buku biografi terkadang kurang meyakinkan. Namun demikian, buku biografi bukan tidak penting untuk dikonsultasi. Penelitian empirispun membuktikan bahwa informasi yang ada dalam buku biografi perawi sangat berharga, meskipun tetap harus didekati secara kritis. ${ }^{14}$

\section{Dekonstruksi Atas Warisan Sejarah Sunnah}

Kata sunnah secara literatur berarti jalan, aturan, atau perilaku hiduh. Kata ini telah digunakan dalam puisi pra-Islam demikian pula dalam al-Qur'an dengan arti yang sama. Siapa saja dapat memperakarsai Sunnah, baik atau buruk, jika hal itu diikuti orang lain. Karena hidup Nabi SAW. merupakan model yang diikuti oleh semua muslim, kata “ Sunnah Nabi" sudah digunakan pada masa hidup Nabi SAW. dan bahkan digunakan oleh beliau sendiri. Kadang-kadang norma-norma yang diambil secara analogis dari praktek atau kata-kata Nabi SAW juga disebut Sunnah ${ }^{15}$. Sedangkan penegasan al-Qur'an bahwa Sunnah adalah sumber Hukum atau sumber etika untuk berkehidupan tidak ada, tetapi secara khusus memerintahkan supaya patuh kepada Rasulullah SAW. dan supaya menyesuaikan dengan contoh-contoh yang beliau perbuat.

Dalam hal ini, penulis melihat perlu verifikasi terhadap pandangan-pandangan Barat dan para sarjana muslim yang sependapat dengan Barat, begitu sarjana muslim yang mendapatkan Barat dalam suatu kesalahan dan penyimpangan sudah seharusnya perlu diverifikasi karena kedua acuannya dalam argumentasinya adalah kelarisifikasi keakuratan referensi masing-masing dan interpretasi-interpretasi terhadap sejarah hadits sehinga menjadi logis.

Penulis melihat dekonstruksi histori hadits adalah logis karena akibat muculnya suatu ilmu hadits itupun dikarena rasionalisasi bahwa manusia tidak luput dari kesalahan dan lupa. Maka usaha-usaha ulama hadis membuat ilmu jarh wa ta'dil, ilmu kritik sanad dan matan hadits adalah usaha verifikasi hadits-hadits yang menjadikan penilitian terhadap hadis-hadis sehingga di katagori kepada shahih, hasan, dho'if, dan palsu.

Permasalah dekonstruksi atas sejarah hadits sangat urgen dalam masa sekarang sangat, karena dari masa umat terdahulu sampai terkini bahwa kelembagaan-kelebagaan gerakan-gerakan yang dijadikan nama organisasi muslim di negara-negara muslim tidak sedikit terjebak dalam pemahaman teks al-Qur'an dan hadisyang mengakibatkan kaum

14 Tentang reliabilitas kitab biografi, lihat Kamaruddin Amin, The Relibility

15 M.M. Azami, Menguji Keaslian Hadits-hadits Hukum, terjemahan, Jakarta: Pustaka Firdaus.2004, h.44 
muslim stagnan, ektrim, dan fanatik. Seperti kasus gerakan salafiy, mereka cenderung untuk kembali kepada teks al-Qur'an dan hadisyang shahih dan mengindahkan para imam mazhab bahwa gerakan ini telah menghambat kemajuan umat muslim, dalam arti mereka menyibukkan pelembagaan karakteristik umat muslim dengan pemahaman teks, contoh"memendekkan kumis dan memanjangkan jenggot" adalah makna dari hadits secara harfiah.

\section{E. Dekonstruksi Atas Warisan Sejarah Ilmu Al-Jarh Wa Al-Ta'dīl}

Penilaian kualifikasi hadis bertolak dari penelitian terhadap sanad yang mentransformasi hadis-hadis Nabi. Kualifikasi hadis terbagi menjadi hadis șaḥiḥ, hasan, dan dạ ‘if.

Dari kepentingan kualifikasi hadis tersebut maka pada abad ketiga, ulama hadis member perhatihan mereka kepada ilmu rijal hadis kemudian berkembang kepada dua cabang ilmu, yakni ilmu tarikh al-ruwah atau ilmu tarikh al-rijal ${ }^{16}$ dan ilmu al-jarh wa alta 'dil ${ }^{17}$ Sehingga melahirkan karya ulama di dua bidang ilmu tersebut, di bidang ilmu tarikh al-ruwah, di antaranya, seperti kitab al-tarikh al-kabir, karya Abu 'Abdillah Muhammad ibn Ismail al-Bukhari(w.256 H), di bidang Ilmu al-Jarh wa al-Ta'dil di antaranya, seperti kitab al-jarh wa al-ta'dil karya Ibn Abi Hatim al-Razi.

\footnotetext{
${ }^{16}$ Secara etimolgis, ilmu tarikh al-ruwah\} berasal dari kata tarich yang artinya sejarah dan alruwah bentuk jama' dari kata al-rawi-yang berarti para perawi. "Ilmu al-Tarich al-Ruwah menjelaskan hal ihwal para perawi yang berkaitan dengan periwayatan hadis yang meliputi informasi tetang kurun hidupnya (tahun lahir dan wafatnya), daerah kelahirannya, guru-gurunya, murid-muridnya, negeri-negeri tempat kediaman gurunya, perlawatannya,tarikh kedatangannya ke negeri-negeri yang dikunjunginnya, pendengaran hadisnya guru sebelum dan sesudah gurunya mengalami ikhtilat - dalam kasus di antara gurunya ada yang mukhtalit\} madhhab yang dipeganginya dan lain-lain yang ada hubungannya dengan periwayatan hadis"lihat- Suryadi "Metodologi Ilmu Rijal Hadis", lihat - Muhammad 'Ajjaj al-Khat\}ib, "Us\}ul al-Hadith 'Ulumuh wa Must\}alah\}uhu”, ( Berut: Dar al-Fikr, 1975),h.253.

${ }^{17}$ Ilmu al-Jarh wa al-Ta'dil, yang secara bahasa al-Jarh berarti luka, cela, atau cacat, adalah ilmu pengetahuan yang mempelajari kecacatan para perawi, seperti pada ke-adilan dan ke-d\}abitannya. Para ahli hadis mendefinisikan al-jarh dengan:"kecacatan pada perawi hadis disebabkan oleh sesuatu yang dapat merusak keadilanya atau kedhabitan perawi".(AL-'Atar,1979:92). Sedangkan menurut istilah ahli hadis lain, adalah:

" Nampak suatu sifat pada rawi yang merusakan keadilannya, atau mencedarakan hafadahnya, karenanya gugurlah riwayatnya atau dipandang lemah".(al-Khathib,1989:261). Adapun al-Ta'di>l secara bahasa berarti At-Taswiyah (menyamakan), dan menurut istilah adalah:

"yaitu lawan dari al-jarh, yang berarti pembersihan atau pensucian perawi dan ketetapan bahwa ia adil atau dhabit".(AL-'Atar,1979:92) Lebih jelasnya, ilmu pengetahuan yang membahas tentang kritikan adanya 'aib atau memberikan pujian adil kepada seorang rawi disebut dengan "Ilmu Jarh wa al- Ta 'dil".

"Ajjaj al-Khatib mendefinisikannya sebagai berikut:"Ialah suatu ilmu yang membahas hal ihwal para rawi dari segi diterima atau ditolak periwayatannya".(AL-Khathib,1989:261). Ulama lain mendefinisikan al-jarh wa al Ta'dil dengan: "Ilmu yang membahas tentang para perawi hadis dari segi yang dapat menunjukan keadaan mereka, baik yang dapat mencacatkan atau mebersihkan mereka, dengan ungkapan atau lafadz tertentu".(Shubhi al-Shalih, 1997:109). Lihat - M. Abduh Almanar menjelas dalam bukunya "Studi Ilmu Hadis", ((Jakarta: Gaung Persada Press, Maret 2011), cet ke -I, h.111.
} 
melahirkan kaidah ilmu jarh wa ta'dill ${ }^{18}$ sebagai ilmu untuk mengkritisi perawi hadis, yaitu, menyebutkan kondisi sifat buruk yang ada pada perawi sehingga hadis yang diriwayatkannya ditolak atau menyebutkan kondisi sifat baik yang ada pada perawi sehingga hadis yang diriwayatkannya dapat deterima sebagai dalil agama. ${ }^{19}$

Sebenarnya, munculnya ilmu jarh wa ta'dil ini adalah bagian perkembangan dari ilmu rijalul hadis. ${ }^{20}$ Bersamaan dengan itu, urgensinya adalah untuk mengetahui hadishadis shahih, hasan, dhaif, dan palsu. Hal itu telah melahirkan tradisi bagi ulama hadis untuk menguji para perawi hadis dengan menguji kejujurannya atau mengetahui kedustaannnya. Sehingga dengan cara demikian, mereka dapat membedakan antara hadis yang bisa diterima dan yang ditolak. Para ulama telah menetapkan lafal-lafal urutan tingkatan dalam penyebutan al-jarah wa al-ta'di l(kondisi sifat buruk pada perawi dan kondisi sifat baik pada perawi) tentang keadaan perawi serta melakukan penelitian. Hal itu dilakukan untuk lebih mengenal secara dekat dengan semua yang berkaitan dengan perawi. Mereka melakukan penelitian yang cermat, sehingga mereka dapat menetapkan kualitas dan krediblitas seorang perawi hadis. ${ }^{21}$

Adapun langkah historis ulama menjadikan ilmu al-jarh wa al-ta'dil sebuah kaidah untuk menilai perawi hadis, memiliki landasan hukum dari al-Qur'an, al- Hadis, dan ijma' ulama. Dalil dari al-Qur'an sebagaimana firman Allah, QS:49:6 : yang artinya, “

18 Ilmu al-jarh, yang secara bahasa berarti luka, cela, atau cacat, adalah ilmu pengetahuan yang mempelajari kecacatan para perawi, seperti pada ke-adilan dan ke-dhabitannya. Para ahli hadis mendefinisikan al-jarh dengan:"kecacatan pada perawi hadis disebabkan oleh sesuatu yang dapat merusak keadilanya atau kedhabitan perawi".(AL-“Atar,1979:92). Sedangkan menurut istilah ahli hadis lain, adalah:

"Nampak suatu sifat pada rawi yang merusakan keadilannya, atau mencedarakan hafadahnya, karenanya gugurlah riwayatnya atau dipandang lemah".(AL-Khathib,1989:261). Adapun at-Ta'dil secara bahasa berarti At-Taswiyah (menyamakan), dan menurut istilah adalah:

"yaitu lawan dari al-jarh, yang berarti pembersihan atau pensucian perawi dan ketetapan bahwa ia adil atau dhabit".( AL-'Atar,1979:92) Lebih jelasnya, ilmu pengetahuan yang membahas tentang kritikan adanya 'aib atau memberikan pujian adil kepada seorang rawi disebut dengan "Ilmu Jarh wa al- Ta;dil".

Dr. Ajjaj Khatib mendefinisikannya sebagai berikut:"Ialah suatu ilmu yang membahas hal ihwal para rawi dari segi diterima atau ditolak periwayatannya".(AL-Khathib,1989:261). Ulama lain mendefinisikan al-jarh wa al Ta'dil dengan: "Ilmu yang membahas tentang para perawi hadis dari segi yang dapat menunjukan keadaan mereka, baik yang dapat mencacatkan atau mebersihkan mereka, dengan ungkapan atau lafadz tertentu".(Shubhi AL-Shalih, 1997:109). Lihat - M. Abduh Almanar menjelas dalam bukunya "Studi Ilmu Hadist", ((Jakarta: Gaung Persada Press, Maret 2011), cet ke-I, h.111.

${ }^{19}$ Muh.Zuhri, Hadis Nabi Telaah Historis \& Metodologis,(Yogyakarta: Tiara Wacana Yogya, 2011), cet.III, h.121.

${ }^{20}$ Ilmu Rijal al-Hadis adalah sejarah kehidupan para tokoh perawi hadis tersebut, meliputi masa kelahiran dan wafat mereka, negeri asal, negeri mana saja tikoh-tokoh itu mengembara dan dalam jangka berapa lama, kepada siapa saja memperoleh hadis dan kepada siapa saja mereka menyampaikan hadis, lihat al-Shadīq Basyī Nashir, dhowābithi al-ruwāh 'inda al- muhadditsī, (Libia: Tharablis, mansyurāt kuliah alda'wah al-islamiyyah 1992), h.212.- Lihat Muh. Zuhri, Hadis Nabi Telaah Historis \& Metodologis, (Indonesia: Yoryakarta, Tiara Wacana 2011), cet.III, h.117-118.

${ }^{21}$ M. Abduh Almanar menjelas dalam bukunya "Studi Ilmu Hadist", ((Jakarta: Gaung Persada Press, Maret 2011), cet ke-I, h.117. 
Hai orang-orang yang beriman, jika datang kepadamu orang fasik membawa berita, maka periksalah dengan teliti agar kamu tidak menimpa suatu musibah kepada suat kaum tanpa mengetahui keadaanya yang menyebabkan kamu menyesal atas perbuatan itu" ${ }^{22}$. Sedang dari al-Hadis ada di dalam kitab al-Imam al-Bukhari yang disyarah fathul al-Bari, pada bab adab, dalam sub bab: dibolehkan berbuat ghibah atas orong-orang yang sering melakukan kerusakan, dan orang yang menimbulkan keraguan, no.hadis 6054. Riwayat ini juga ada di dalam kitab shahih Muslim, bab al-bir,wa al-shillah, dan al-Adab, dalam sub bab: fi madāri man yattaqi fahsyahu,no. hadis 73. Dan 'ijma'al-muslimin, seperti al-Imam al-Tsaur ${ }^{23}$

Di masa sahabat, histori tentang perbuatan usaha-usaha menyebutkan kondisi sifat baik perawi dan kondisi sifat buruk perawi sudah pernah dilakukan para sahabat di antaranya Umar bin al-Khathāb, Ali bin Abi Thālib, Abdullah bin Salām, Ubādah bin alShāmit, Adullah bin Abbas, Anas bin Mālik, dan Aisyah bin Ab̄̄ Bakar al-Shiddīq. ${ }^{24}$

Sedangkan perkembangan historiografi di masa tābi'̄i tentang al-jarah wa alta'dil, ulama tidak banyak menemukan para perawi hadis yang memiliki kondisi sifat buruknya (al-jarh), sebaliknya, ulama lebih banyak menemukan kondisi sifat baiknya perawi hadis. Karena di antara sebabnya, bahwa masa mereka masih dekat dekat dengan masa kenabian dan sahabat. Namun, tidak juga mereka terlepas dari perawi yang kondisi keburukannya (al-jarh) tetap ada, tetapi sedikit sekali, disebabkan beberapa faktor, seperti keterlibatan perawi dalam mazhab yang buruk seperti khawarij, lemah hafalannya, dan karena kebodohannya.

Adapun dari imam yang paling terkenal pada masa ini yang menerapkan ilmu aljarh wa ta'dil dengan ketat adalah iman al-Sya'bi, ibn Sìrin, kemudian Sa'id bin alMusaib, Sa'id bin Jabīr, al-Zuhrī, Athā, al-A'raj dan lainnya.

Al-Dzahabī (w.748 H) berkata: "bahwasanya ulama yang pertama-tama memberikan penjelasan-penjelasan tentang para perawi hadis dari kondisi sifat kebaikan (al-ta'dil) dan kondisi sifat keburukan adalah Al-Sya'bi dan Ibn Sirin dan juga ulamaulama selain mereka, menjadi tempat pertanyaan pada masa itu tentang al-jarh wa alta'dil, dan mereka telah banyak menghafal jumlah perawi yang memiliki kondisi sifat kebaikan dari pada sifat keburukannya, karena guru-guru mereka masih sahabat yang 'adul

\footnotetext{
${ }^{22}$ Tarjamhan al-Qur'an Depag, ( Jakarta 1 Maret 1971).

${ }^{23}$ Zuhair 'Ustmān 'Ali Noor, Ibn 'Udā wa manhajuhu fi dhuafā'i al-Rijal,( Saudi Arabia:Riyad, makatab al-Rasyīd,1997), cet.I, h.19.

${ }^{24}$ Zuhair 'Ustmān 'Ali Noor, h. 19
} 
lagi juga 'alim dan orang-orang biasanya pada masa itu masih orang-orang yang memiliki kredibilitas dan yang dapat dipercaya".

Kemudian perkembangan histori berikutnya, yaitu pada masa akhir tabi'in, telah ada nama-nama ulama yang memperhatikan tentang ilmu al-jarh wa ta'dil, seperti: AlAuja'i, Syu'bah, Anas bin Malik, Hasyim bin Basyi, Sufyan bin 'Uyaynah, Sufyan bin alTsauri, Hammad bin Salamah, Hammad bin Zaid, Al-Laits bin Sa'ad, dan Abdullah bin Al-Mubaarak, dan dijelaskan pada masa ini telah terjadi jumlah besar dari perawi hadis lemah, pembohong, juga perawi orang-orang sangat bodoh. Kemudian masa berikutnya adalah masa 'atbā al-täbi'in, yang dikabarkan pada masa inilah ,bahwa ulama hadis sangat menyibuk dirinya untuk ilmu al-jarh wa al-ta'dīl, seperti: Ibn Muhd̄̄, Yahya alQathān, Waki' bin al-Jarrāh, Abu Na'̄̄m, Abu Mushar, Abu Dawūd al-Thayālisī, Sa’̄̄d bin Manshūr.

Akan tetapi, sampai abad pertengahan yaitu abad kedua Hijriah, perkataanperkataan ulama ini belum terkumpulkan dan disusun. Lalu setelah itulah, datang masa kompilasi dan kodifikasi buku-buku induk Sunnah Nabi, maka perbincangan ulama al-jarh wa al-ta'dīl tentang rijal al- hadis (perawi hadis) sudah tertulis dalam kertas yang kemudian dikompilasikan dan dikodifikasi. Di antara ulamanya pada masa ini adalah Yahya bin Mu'īn sebagai ketua ulama al-jarh wa ta'd $\bar{l} l$, dan ulama lainnya, seperti: 'Ali bin al-Madīn̄̄, Ahmad bin Hambal, Ibn Sa'ad, Abu Khaytsamah, Khalīfah bin Khayyāth, al-Falās, Abu Bakar bin Abi Syaybah, dan Dahīm. Kemudian diikuti para muridnya masih pada masa ini, seperti: al-Bukhari, Muslim, al-Dzahilī, Abu Zar'ah, Abu Hātim al-Raziyān, Abu Dāwud al-Sijistānī, dan lainnya. Dan tingkatan ulama berikutnya yang mengikuti jalan mereka adalah Abdān al-Ahwāzi, al-Nasāi, Abu 'Arūbah al- Harrān̄i, 'Aliyyak alRāzī, Ibn Hibbān, Ibn 'Udā, Ibn Abi Hātim al-Raz̄i dan lainnya. Hal ini, masih terus berkembang samapai pada akhir abad ke sembilan perhatian ulama hadis meneliti kondisi perawi hadis dan menjelaskan keshahihan Sunnah Nabi.

Maka telah banyak kontribusi ilmu al-jarh wa ta'dīl dalam perkembangan historiografi islam, yang disusun dalam bermacam model; kitab rijal dan sejarahnya yang mencatat shabat saja, seperti: al-Isti'āb fi Ma'rifah Shābah, karya Ibn 'Abdu al- Barri, kitab Asa al-Ghābah fi Ma'fah al-Shābah, karya al-Atsir al-Jazrī, kitab al-Ishābah fi Tamyiyz al-Shābah karya Ibn Hajar al- 'Asqalāni, dan kitab yang disusun atas dasar altabaqāt, seperti, kitab al-Tabaqāt karya Khalīfah bin Khayyāth, kitab al-Tabaqāt alKubrā, karya Ibn Sa'ad, kitab Tadzkirah al- Huffazh karya al-Dzahabī, dan model yang disusun tanpa pengkhususan, seperti kitab Tārīkh Nisābūri karya al-Nisābūri, kitab Tārīkh 
Jurjāni karya al-Sahimī, kitab Tārīkh Baghdād karya al-Khāthīb al- Baghdādi, dan seterusnya menjadi leteratur bagi perkembangan historiografi islam yang dapat dijadikan referensi-referensi bagi pencinta peneliti kitab-kitab Sunnah Nabi dan masih terjaga sampai sekarang ini. ${ }^{25}$

Pada prinsipnya, ilmu jarh wa ta'dil adalah bentuk lain dari upaya untuk meneliti kualitas pewari (rijāl al- hadis) sehingga hadis bisa diterima (maqbūl) atau ditolak (mard $\bar{u} d)$. Hal tersebut, yang menjadi objek penelitiannya selalu mengarah pada dua hal penting, yang pertama berkaitan dengan sanad/rawi (rangkaian yang menyampaikan) hadis, dan kedua berkaitan dengan matan (redaksi) hadis. Dengan demikian keberadaan sanad dan matan menjadi dua hal yang tidak bisa dipisahkan.

Ilmu yang berkaitan dengan sanad akan megantar kepada penelusuran apakah sebuah hadis itu bersambung sanadnya (muttashi) atau tidak ( munqathi'), dan apakah para periwayat hadis yang dicantumkan di dalam sanad hadis itu orang-orang terpercaya atau tidak. Adapun Ilmu yang berkaitan dengan matan akan membantu pengetahuan tentang apakah informasi yang terkandung dalam matan hadis berasal dari Nabi atau tidak. Misalnya, apakah kandungan hadis bertentangan dengan dalil al-Qur'an.

\section{F. Kesimpulan}

Tulisan ini menghendaki adanya dekonstruksi terhadap al-hadists, Karena rasionalisasi sejarah dan metode pembukuan sejarah dengan hanya mengandalkan metode kritik sanad saja, yang digerakkan ulama hadits pada abad paroh kedua dan paruh abad ketiga Hijriah $^{26}$. Kemudian telah pengertian terhadap Sunnah bagi umat Islam adalah suatu permasalahan karena kesalahan-kesalahan interpretasi terhadap sunnah dan karena keinginan pelembangaan pemahaman umat Islam. Hal itu telah menutup kemajuan umat Islam dalam berkehidupan.

Dalam sejarah umat Islam, reliabilitas ulumul hadis tidak pernah mendapat tantangan berarti dari sarjana Islam. Ada beberapa sarjana yang meragukan reliabilitasnya, tapi tidak mendapat simpati berarti dari umat Islam $^{27}$.

Kegiatan Barat dengan para orientalis dalam penelitian penelitian keilmuan islam itu adalah motivasi dalam mendapat keakurasian suatu referensi ajaran islam, maka angumentasi-argumentasi dengan mengajukan adanya metode-metode baru seperti

\footnotetext{
${ }^{25}$ Ibid. $20-23$

26 Ali Mutafa Yakub, Kritik Hadis, Jakarta: Pustaka Firdaus,2008, h.5

27 http://www.grahadis.uim.ac.id/index.php.optio
} 
perlunya dekonstruksi dan konstruksi terhadap hadisadalah kemajuan berpikirnya Barat dari pada muslim yang cenderung stgnan, fanatis, dan tertup.

Perhatian ulama hadis dengan kualifikasi hadis shahih,hasan, dha'if dan palsu, melahirkan kaidah ilmu al-Jarh wa al-Ta'dīl melalui penelitian atau perhatian kepada sanad (para periwayat hadis). Sehingga melahirkan banyak dokumentasi-dokumentasi monumental atas rijal hadis dan komentar ulama terhadap para periwayat hadits-hadits.

\section{G. Daftar Pustaka}

Yaqub, Ali Mustafa, Kritik Hadis, Jakarta : Pustaka Firdaus, 2008.

Soebari, Erfan, Menguak Fakta Keafsaan Al-Sunnah, Prenada Media, 2003.

Azami, M.M, Menguji Keaslian Hadis-Hadis Hukum - Sanggahan atas The Origins of Muhammadan Jurisprudence - Joseph Schacht, Jakarta : Pustaka Firdaus, 2004

al-Adlabi, Salahudin ibn Ahmad, Metodologi Kritik Matan Hadis, Ciputat Tangerang : Penerbit Gaya Media Pratama, 2004.

Ismail, Syuhudi Ismail, Kaidah Kesahihan Sanad Hadis - Telaah Kritik dan Tinjauan dengan Pendekatan Ilmu Sejarah, Jakarta : Bulan Bintang, 2005.

Yuslim, Nawir, Ulumul Hadis, Jakarta : Mutiara Sumber Widya, 2001.

al-Khathib, M.'Ijjaj, Ushul hadis-wa- 'Ulumuh-wa-Mushthalahu, Lubnan : Dar-Al-Fikral-Hadits, 1967 .

al-Asqalani, Ibn Hajar, Tabaqat al-mudallisisn, Cairo, 1322.

al-Mizzi, Tahdhib al-kamal, vol. 6, 125; Ibn Sa'd, Tabaqat, vol. 7.

Al-Razi, al-Jarh wa al-tadil, vol. 8.

al-Asqalani, Ibn Hajar, Tahdhib al-tahdhib, vol. 9 .

Almanar, M. Abduh, Studi Ilmu Hadis, Jakarta : Gaung Persada Press, Maret 2011, cet ke1 .

Zuhri, Muh., Hadis Nabi Telaah Historis \& Metodologis, Yogyakarta : Tiara Wacana Yogya, 2011 , cet ke-3.

Ali Noor, Zuhair 'Ustmān, Ibn 'Udā wa manhajuhu fi dhuafā'i al-Rijal, Saudi Arabia :

Riyad, makatab al-Rasyīd, 1997.

http://www.grahadis.uim.ac.id/index.ph 